\title{
Unilateral pleural effusion in a peritoneal dialysis patient
}

\author{
Abhilash Koratala, Vikrampal Bhatti
}

Department of Nephrology, University of Florida College of Medicine, Gainesville, Florida, USA

\section{Correspondence to} Dr Abhilash Koratala, akoratsla@ufl.edu

Accepted 27 August 2016
CrossMark

To cite: Koratala $A$, Bhatti V. BMJ Case Rep Published online: [please include Day Month Year] doi:10.1136/bcr-2016216637

\section{DESCRIPTION}

Massive pleural effusion is a rare complication of peritoneal dialysis $(\mathrm{PD})$ which can progress quickly to cause acute respiratory distress. Delay in diagnosis may result in recurrent hospitalisations and expose patients to unnecessary medications and imaging without improvement of symptoms.

A 61-year-old woman with history of end-stage renal disease secondary to diabetic nephropathy, on continuous cycling PD for 9 months, hypertension and congestive heart failure with preserved ejection fraction presented to the emergency room with shortness of breath of 1-week duration associated with pleuritic chest pain. She also reported of having low drain volumes with the PD. Chest X-ray showed a large unilateral right pleural effusion (figure 1B). Chest X-ray 1-year prior to presentation was normal (figure 1A). Thoracentesis revealed

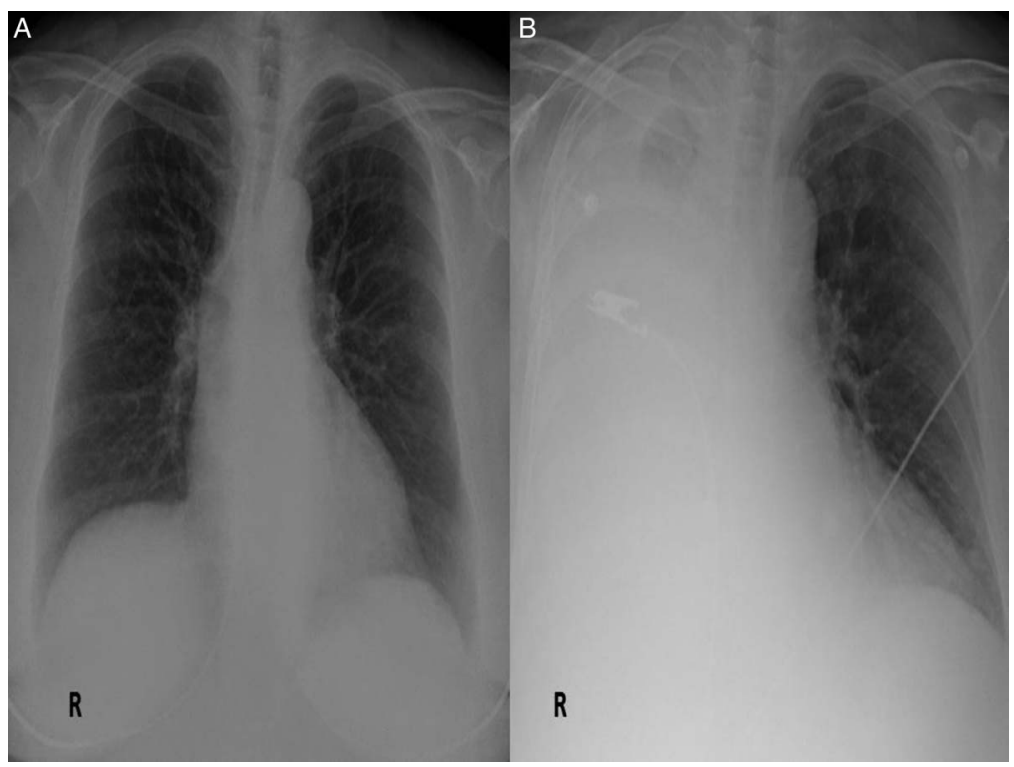

Figure 1 Chest X-ray (A) 1-year prior to presentation which is normal (B) at presentation showing large right pleural effusion and atelectasis.

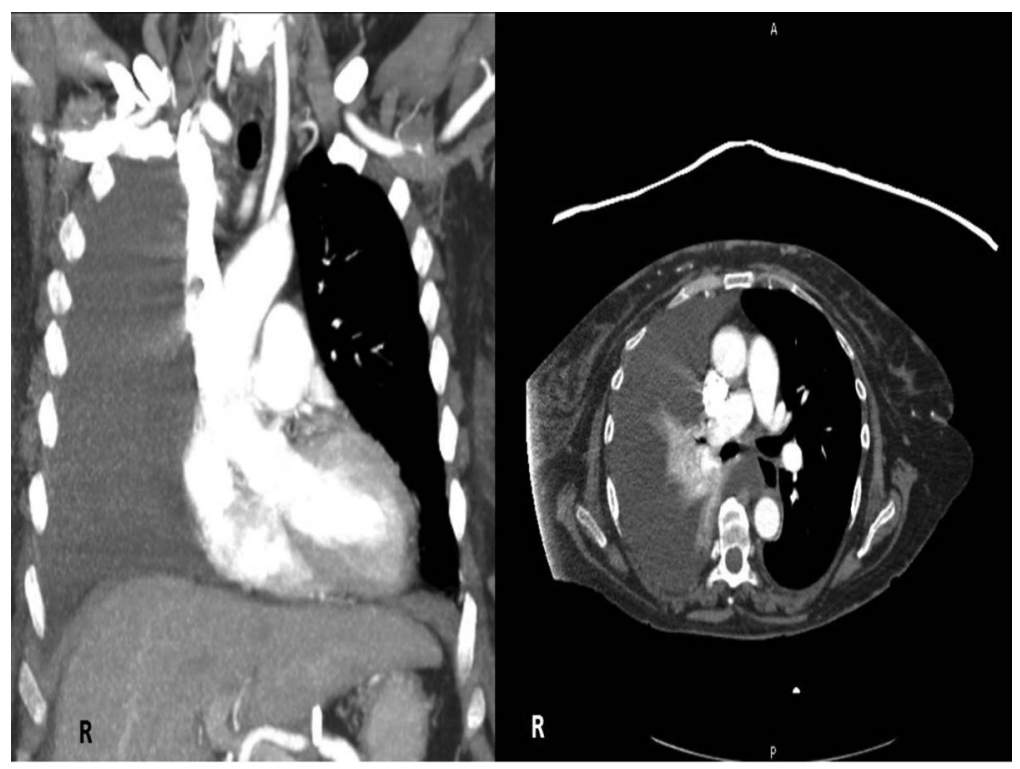

Figure 2 CT chest with contrast showing large right-sided pleural effusion completely occupying right thoracic cavity with complete collapse of the right lung. 


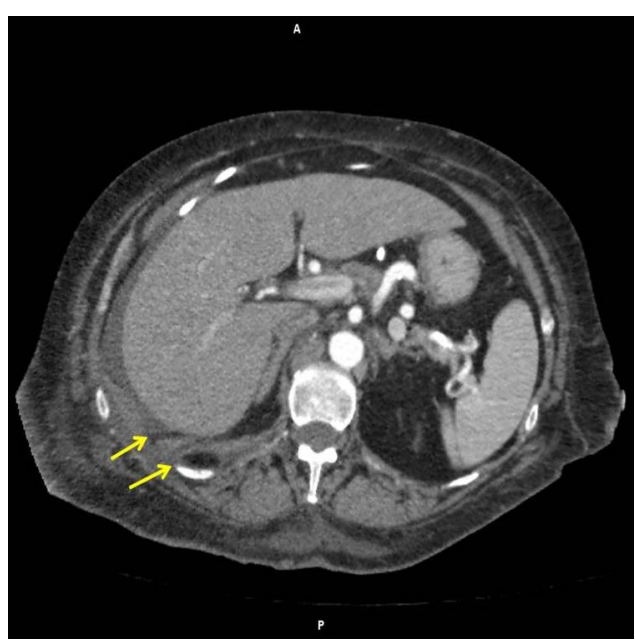

Figure 3 CT chest with contrast showing small diaphragmatic hernia containing fat on the right posterior aspect (yellow arrows) that resulted in the pleuroperitoneal leak.

1.5 $\mathrm{L}$ of clear transudative fluid and culture was negative. She was later discharged home with diuretics and plan for close follow-up. She presented 5 days after the discharge, with respiratory distress and found to have absent breath sounds on the right. CT chest revealed massive right pleural effusion (figure 2) and a small diaphragmatic hernia containing fat on the right posterior aspect (figure 3). She underwent thoracentesis with removal of $1.2 \mathrm{~L}$ sterile transudative fluid. Pleural fluid glucose was $268 \mathrm{mg} / \mathrm{dL}$ with simultaneous blood glucose of $87 \mathrm{mg} / \mathrm{dL}$. We diagnosed pleuroperitoneal leak and temporarily switched her to haemodialysis. She subsequently underwent right thoracoscopy with diaphragmatic defect stapling and talc pleurodesis.

\section{Learning points}

- Patients on peritoneal dialysis (PD) presenting with marked pleural effusion (particularly unilateral) should prompt clinicians to consider the differential diagnosis of pleuroperitoneal leak to avoid recurrent symptoms, unnecessary imaging and procedures.

- A high glucose concentration in the pleural fluid is pathognomonic for this condition, as no other cause of pleural effusion has a marked elevation of glucose compared to serum levels. ${ }^{1}$

- Management includes temporary cessation of PD, pleurodesis and/or video-assisted thoracoscopic surgery. ${ }^{2}$

Contributors AK acquired the data and drafted the article. VB revised the article critically for important intellectual content. AK and VB approved the version to be submitted.

Competing interests None declared.

Patient consent Obtained.

Provenance and peer review Not commissioned; externally peer reviewed.

\section{REFERENCES}

1 Szeto CC, Chow KM. Pathogenesis and management of hydrothorax complicating peritoneal dialysis. Curr Opin Pulm Med 2004;10:315-19.

2 Maude RR, Barretti M. Severe "sweet" pleural effusion in a continuous ambulatory peritoneal dialysis patient. Respir Med Case Rep 2014;13:1-3.

Copyright 2016 BMJ Publishing Group. All rights reserved. For permission to reuse any of this content visit

http://group.bmj.com/group/rights-licensing/permissions.

BMJ Case Report Fellows may re-use this article for personal use and teaching without any further permission.

Become a Fellow of BMJ Case Reports today and you can:

- Submit as many cases as you like

- Enjoy fast sympathetic peer review and rapid publication of accepted articles

- Access all the published articles

- Re-use any of the published material for personal use and teaching without further permission

For information on Institutional Fellowships contact consortiasales@bmjgroup.com

Visit casereports.bmj.com for more articles like this and to become a Fellow 